\title{
Evaluation of Rhizospheric Bacteria from Ocimum sp. as Potential Pgpr
}

\section{Baljeet Singh Saharan ${ }^{1 *}$ and Shuchita Verma ${ }^{2}$}

${ }^{1}$ Department of Plant Pathology, Washington State University, Pullman, WA, USA

${ }^{2}$ Department of Microbiology, Microbial Resource Technology Laboratory, Kurukshetra University, Kurukshetra, India

\begin{abstract}
In the present investigation, 24 rhizospheric soil samples of Ocimum sp. were collected from different vicinities of Delhi, Kurukshetra and Haridwar (India). A total of 266 bacterial strains were isolated and screened for in vitro plant growth promoting trait. About $86.46 \%$ bacterial isolates showed ammonium production, $89.09 \%$ exhibited phosphate solubilization and $87.59 \%$ for catalase production whereas only $7.14 \%$ showed positive reaction for HCN production. Five isolates viz., $\mathrm{CHII}(\mathrm{II}) \mathrm{K} 7, \mathrm{CHIII}(\mathrm{I}) \mathrm{Y} 6, \mathrm{DDI}(\mathrm{I}) 1, \mathrm{UHI}(\mathrm{II}) 7$ and $\mathrm{CHII}(\mathrm{I}) \mathrm{NA} 4$ were found to exhibit maximum number of plant growth promoting traits.
\end{abstract}

Keywords: PGPR; PGP traits; Ocimum; IAA; Medicinal plant; Bioinoculant

\section{Introduction}

Micro-organisms play a vital role in recycling of nutrients. They offer an attractive way for sustainable agricultural system by reducing the use of chemical fertilizers [1-3]. Most of the world population still relies mainly on herbal products and medicines for health care $[4,5]$. India has a rich heritage of medicinal plants. These are storehouse of antimicrobial agents. They offer advantage of being safer and pose lesser side effects [6]. The relationship between PGPR and medicinal plants is yet to be explored. PGPR are beneficial bacteria that help in plant growth. Mechanisms of PGPR are solubilization of phosphate, $\mathrm{N}_{2}$ fixation, siderophore production, phytohormone synthesis, ACC deaminase activity, ISR, production of antibiotics and enzymes that lyse cell wall of fungal pathogens [7-11]. PGPR traits have been recorded in several bacteria and cyanobacteria species belonging to Acinetobacter, Azotobacter, Bacillus, Beijernckia, Burkholderia, Enterobacter, Pseudomonas, Rhizobium and Serratia [12-15]. Understanding interactions between PGPR and plants will be helpful for developing strategies for plant growth enhancement. Chemical fertilizers being highly expensive and extremely hazardous to environment may pose a serious threat to human health. A system is therefore required to replace these chemical means so that ecologically sustainable biocontrol strategy can be developed and this can be achieved by use of efficient PGPR strains that can be used for the management of plant pathogens as well as for achieving good yields of crops.

One of the most valuable medicinal plants is Ocimum (tulsi or basil) that belongs to family Lamiaceae and bears a high medicinal value [16]. Ocimum sanctum is also known as "The Incomparable One", "The Mother Medicine of Nature", and "The Queen of Herbs"[17]. Tulsi improves digestive system and possess properties such as antiulcer activity, anti-stress activity, anti-carcinogenic, anti-oxidant, antimicrobial, anti-diabetic and anti-inflammatory. It provides protection against cardiac and neurological disorders. Tulsi provides strength to the immune system [16]. Traditionally, it is used to treat asthma [18] with growing interest in finding eco-friendly methods for sustainable agriculture, it is necessary to explore soil microbial diversity for PGPR having combination of plant growth promoting traits. Keeping these points in mind, the aim of our work was to evaluate various microbial (bacterial) isolates from Ocimum rhizosphere for their plant growth promoting traits and suitability for their application to improve the yield of this very important medicinal plant i.e. Ocimum sp.

\section{Materials and Methods}

\section{Sampling sites and collection of soil sample}

For isolation of potential rhizobacterial strains, sampling of rhizospheric soil with intact root system was done carefully with the help of sterile equipments. The rhizospheric soil samples (twenty-four) of Ocimum plants were collected from different localities in Delhi, Haridwar and Kurukshetra (India) during the month of June-July (Table 1). The top soil containing dry matter was removed from the sampling site and entire root system along with the rhizosphere soil was collected digging up to $15 \mathrm{~cm}$ in depth. Samples were taken from the upper as well as lower region of rhizosphere. The samples were then placed in sterile plastic bags and stored at $4^{\circ} \mathrm{C}$ (Figures 1-3).

\section{Isolation and characterization of bacteria from Ocimum rhizosphere}

A total of 266 bacterial isolates were obtained from 24 rhizospheric soil samples of Ocimum sp. Isolation was done by Serial Dilution technique on different media such as Nutrient agar medium, Kings B medium, YEMA medium, Ashby medium and Pikovaskaya medium by incubating plates at $28^{\circ} \mathrm{C}$ for 3 days (Table 2). About $10 \mathrm{gm}$ of rhizosphere soil was mixed with $90 \mathrm{ml}$ of sterile distilled water in a flask and shaken for 10 minutes on a rotary shaker. Following this, 1 $\mathrm{ml}$ suspension from the flask will be added to $10 \mathrm{ml}$ vial and successive dilutions were made upto $10^{-7}$ dilution. About $0.1 \mathrm{ml}$ of this suspension was spread on respective media plates. The plates were observed for typical bacterial colonies and well isolated single colonies were picked up for streaking on fresh respective agar plates to get the pure cultures [19]. All the isolates were studied for their morphological characteristics. Different morphological characteristics of colonies such as color, elevation, shape, size, etc. were recorded after 3 days of incubation.

*Corresponding author: Baljeet Singh Saharan, Department of Plant Pathology Washington State University, Pullman, WA, USA, Tel: +1 509-335-3564; E-mail: Baljeet.kuk@gmail.com

Received January 20, 2015; Accepted March 17, 2015; Published March 24 2015

Citation: Saharan BS, Verma S (2015) Evaluation of Rhizospheric Bacteria from Ocimum sp. as Potential Pgpr. J Microb Biochem Technol 7: 088-095. doi:10.4172/1948-5948.1000187

Copyright: (c) 2015 Saharan BS, et al. This is an open-access article distributed under the terms of the Creative Commons Attribution License, which permits unrestricted use, distribution, and reproduction in any medium, provided the original author and source are credited 


\begin{tabular}{|c|c|c|c|}
\hline S. No. & Sample & Locality & No. of isolates \\
\hline 1 & $\mathrm{CHI}(\mathrm{I})$ & Haridwar & 24 \\
\hline 2 & $\mathrm{CHI}(\mathrm{II})$ & Haridwar & 25 \\
\hline 3 & $\mathrm{CHII}(\mathrm{I})$ & Haridwar & 21 \\
\hline 4 & CHII(II) & Haridwar & 18 \\
\hline 5 & $\mathrm{CHIII}(\mathrm{I})$ & Haridwar & 27 \\
\hline 6 & $\mathrm{CHIV}(\mathrm{I})$ & Haridwar & 26 \\
\hline 7 & KUKI(I) & Kurukshetra & 22 \\
\hline 8 & KUKI(II) & Kurukshetra & 08 \\
\hline 9 & $\mathrm{DDI}(\mathrm{I})$ & Delhi & 04 \\
\hline 10 & $\mathrm{DDI}(\mathrm{II})$ & Delhi & 07 \\
\hline 11 & DDII(I) & Delhi & 05 \\
\hline 12 & DDII(II) & Delhi & 04 \\
\hline 13 & DDIII(I) & Delhi & 13 \\
\hline 14 & DDIII(II) & Delhi & 10 \\
\hline 15 & $\operatorname{DDIV}(I)$ & Delhi & 02 \\
\hline 16 & $\operatorname{DDIV}(I I)$ & Delhi & 09 \\
\hline 17 & $\operatorname{DDV}(\mathrm{I})$ & Delhi & 04 \\
\hline 18 & $\mathrm{DDV}(\mathrm{II})$ & Delhi & 06 \\
\hline 19 & DDVIIII) & Delhi & 03 \\
\hline 20 & DDVII(II) & Delhi & 02 \\
\hline 21 & $\mathrm{UHI}(\mathrm{I})$ & Haridwar & 09 \\
\hline 22 & $\mathrm{UHI}(\mathrm{II})$ & Haridwar & 08 \\
\hline 23 & UHII(I) & Haridwar & 06 \\
\hline 24 & UHII(II) & Haridwar & 03 \\
\hline
\end{tabular}

Table 1: List of soil samples and isolates obtained.
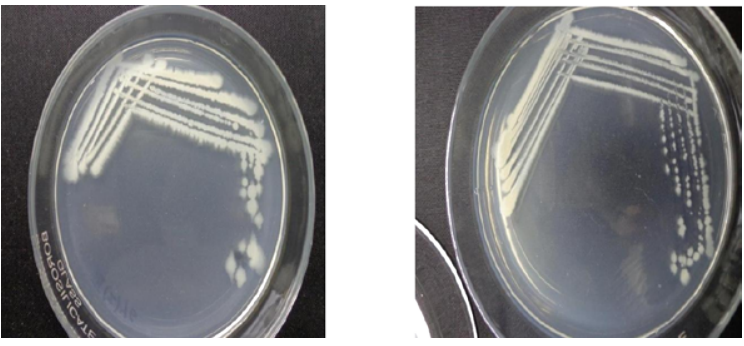

Figure 1: Isolates $\mathrm{UHI}(\mathrm{II}) 7$ and $\mathrm{CHIII}(\mathrm{I}) \mathrm{Y} 6$ grown on nutrient media plates.

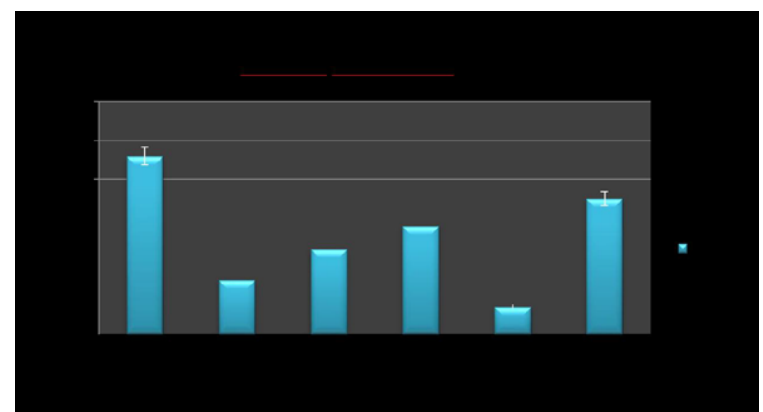

Figure 2: IAA production in the presence of tryptophan from Ocimum rhizosphere isolates.

In vitro screening of bacterial isolates for their plant growth promoting (PGP) activities

Production of Indole acetic acid: Indole acetic acid (IAA) production by the isolates was assayed colorimetrically [20]. Bacterial cultures were grown in LB medium amended with $100 \mathrm{mg} / \mathrm{l}$ tryptophan as the precursor of IAA by incubating in a shaker at $250 \mathrm{rpm}$ at 28 $\pm 2^{\circ} \mathrm{C}$ for seven days. After one week of growth, the cultures were centrifuged at $4000 \mathrm{rpm}$ for $20 \mathrm{~min}$ and the supernatant collected and IAA in the supernatants were quantified by using colorimetric assay. Two milliliter of cell free extract was mixed with $4 \mathrm{ml}$ Salkowski reagent $\left(1 \mathrm{ml}\right.$ of $0.5 \mathrm{M} \mathrm{FeCl}_{3}$ in $50 \mathrm{ml}$ of $\left.35 \% \mathrm{HClO}_{4}\right)$ and absorbance of the resultant pink color was read after $30 \mathrm{~min}$ at $535 \mathrm{~nm}$ in colorimeter. Appearance of pink color in test tubes indicated IAA production. The IAA production was calculated from standard curve and the result was expressed as $\mu \mathrm{g} / \mathrm{ml}$ over control [21].

Production of ammonia: All isolates were tested for ammonia production. The cultures were inoculated in $10 \mathrm{ml}$ peptone water and incubated for $72 \mathrm{~h}$ at $36^{\circ} \mathrm{C}$. After incubation, $0.5 \mathrm{ml}$ of nessler's reagent was added to each tube. Development of brown to yellow color was taken as a positive test for production of ammonia [22].

Production of $\mathrm{HCN}$ : The isolates were tested for $\mathrm{HCN}$ production [23]. Bacteria was inoculated on the nutrient media plates containing $4.4 \mathrm{~g}$ glycine per liter. To the top of the plate, whatman filter paper no. 1 soaked in $2 \%$ sodium carbonate in $0.5 \%$ picric acid solution was placed and sealed with parafilm. The plates were incubated at $36^{\circ} \mathrm{C}$ for 4 days. Plates were observed for the development of orange to red color of filter paper. This was recorded as positive test for HCN production.

Phosphate solubilization: All the bacterial isolates were tested in vitro for their phosphate solubilizing activity using Pikovaskaya's medium. The culture was spot-inoculated on the Pikovskaya medium plates and incubated at $28^{\circ} \mathrm{C}$ for 7 days. The appearance of clear zone around bacterial growth was taken as a positive test for phosphate solubilization [24].

Catalase test: Catalase test was done by adding 3 drops of $3 \%$ hydrogen peroxide to the bacterial culture. Appearance of effervescence was taken as positive test for catalase activity [22].

Antifungal activity: A $9 \mathrm{~mm}$ PDA culture disc from the plates of Fusarium oxysporum, growing in petridishes was cut individually from 7-day-old culture. This was placed on one side of the previously plated sterilized modified PDA medium (g/500 ml PDA (Hi Media)-19.5, peptone- 1 , yeast extract- 0.5 , agar-2.5) approximately $1.5 \mathrm{~cm}$ away from the edge of the plate. Simultaneously, the bacterial isolate was streaked onto the opposite side of the petri plate. The plates were incubated at $28^{\circ} \mathrm{C}$ for 7 days and results were recorded [25]. The level of inhibition was calculated by subtracting the distance $(\mathrm{mm})$ covered by the growth of fungus in the direction of the bacterial isolate from the fungal radius. The percent inhibition was calculated as:

$\%$ inhibition $=(\mathrm{R}-\mathrm{r}) / \mathrm{R} \times 100$ where ' $\mathrm{r}$ ' is radial growth of fungus opposite the bacterial growth and ' $R$ ' is the radial growth of fungus in control plate.

Siderophore production: Siderophores production by the isolates was assayed using plate assay. The tertiary complex (Chrome azural $\mathrm{S}$ (CAS) $/ \mathrm{Fe}^{3+}$ hexadecyl trimethyl ammonium bromide) served as an indicator. The selected isolates were streaked on to the succinate medium mixed with indicator dye. Formation of bright zone with yellowish fluorescent color in the dark colored medium indicated siderophore production [26].

ACC-deaminase activity: Selected bacterial isolates were cultured in DF salt minimal medium [27] at $28^{\circ} \mathrm{C}$ for 2 days with shaking at $200 \mathrm{rpm}$. Centrifuged the culture at $5000 \mathrm{rpm}$ for $5 \mathrm{~min}$ and washed with minimal medium. suspended the cell pellets minimal medium supplemented with $1 \mathrm{mM}$ ACC and incubated at $28^{\circ} \mathrm{C}$ for $24 \mathrm{~h}$ with shaking at $200 \mathrm{rpm}$. ACC deaminase activity was measured according 
to a modification of the method of Honma and Shimomura (1978). The standard concentration curve of $\alpha$-ketobutyrate was generated. All series of known $\alpha$-ketobutyrate concentrations was prepared in $200 \mu \mathrm{l}$ volume and mixed with $300 \mu \mathrm{l}$ of 2,4- dinitrophenylhydrazine reagent. Incubated the contents at $30^{\circ} \mathrm{C}$ for $30 \mathrm{~min}$ for the development of phenylhydrazone. The color of the phenylhydazone was developed by the adding $2 \mathrm{ml} 2 \mathrm{M}$ sodium hydroxide, following which, absorbance of the mixture was measured at $540 \mathrm{~nm}$ [28].

Heavy metal tolerance: The selected isolates were tested for their resistance to heavy metals namely $\mathrm{Ni}, \mathrm{Hg}, \mathrm{Co}, \mathrm{Cd}, \mathrm{Cu}, \mathrm{Pb}, \mathrm{Zn}$ and $\mathrm{Cr}$ by agar dilution method [29]. Nutrient agar plates amended with various soluble heavy metal salts at concentrations $25 \mu \mathrm{g} / \mathrm{ml}, 100 \mu \mathrm{g} /$ $\mathrm{ml}$ and $400 \mu \mathrm{g} / \mathrm{ml}$ were inoculated and incubated for 3 days at room temperature. Heavy metal tolerance was indicated by the appearance of bacterial growth and results recorded.

Effect of temperature on growth of isolates: Chosen isolates were streaked on the nutrient media plates. The plates were incubated at $10^{\circ} \mathrm{C}, 20^{\circ} \mathrm{C}, 28^{\circ} \mathrm{C}, 37^{\circ} \mathrm{C}$ and $45^{\circ} \mathrm{C}$ for 3 days. After incubation, the plates were observed for growth and results were noted.

Statistical analyses: Statistical analysis of the tests was carried out using SPSS 16.0 design. All the tests were conducted in triplicate. Data reported as mean \pm standard deviation (SD). Also, data was analyzed with standard error at $0.5 \%$ significance.

Biochemical characterization: The biochemical tests such as indole test, methyl-red test, vogues-proskauer test, citrate utilization, catalase test, oxidase test, $\mathrm{H}_{2} \mathrm{~S}$ production test, carbohydrate fermentation etc., were performed according to the standard procedures [30].

\section{Results and Discussion}

\section{Isolation and morphological characterization of isolates}

In the present study, 266 bacterial isolates were screened in vitro for PGP activities. Properties such as ammonia production and phosphorus solubilization are found among large no. of bacteria. About 230 (86.46\%) bacterial isolates showed ammonium production, $179(89.09 \%)$ exhibited phosphate solubilization and 233 (87.59\%) for catalase production. Only 19 (7.14\%) showed positive test for HCN

\begin{tabular}{|l|l|}
\hline Culture Medium & Bacteria isolated \\
\hline Nutrient agar medium & Bacillus sp. \\
\hline Kings B medium & Pseudomonas sp. \\
\hline YEMA medium & Rhizobium sp. \\
\hline Ashby medium & Azotobacter sp. \\
\hline Pikovaskaya medium & Phosphate solubilizing bacteria \\
\hline
\end{tabular}

Table 2: Isolation of bacteria from respective culture medium. production. All the isolates were morphologically characterized. Based on the properties, 10 best isolates were selected for further investigation. These isolates were characterized and their morphological characteristics have been studied. Different characteristics of colonies such as color, shape, size, elevation etc., were noted (Table 3 ).

\section{PGP traits of the selected bacterial isolates}

In the present study, some of the isolates could exhibit more than three or four PGP traits, which may promote plant growth directly or indirectly. As shown in Table 4, isolates CHIII(I)Y6, CHII(I)NA4, CHII(II)K7, DDI(I)1were found to exhibit seven different PGP traits whereas isolate UHI(II)7, exhibit six PGP traits; DDII(II)1 exhibit five PGP traits whereas isolates UHII(II)1, DDVII(II)1, KUKI(II)6, and DDV(I)3 exhibit four PGP traits i.e., ammonia production, phosphate solubilization, catalase production and heavy metal tolerance.

IAA production, ammonia production and $\mathrm{HCN}$ production by selected isolates: Six isolates out of ten showed IAA production, viz., CHII(II)K7, CHIII(I)Y6, DDI(I)1, UHI(II)7, DDII(II)1 and CHII(I) NA4 (Figure 2). Ammonia production was observed in all selected isolates. Isolate $\mathrm{CHII}(\mathrm{II}) \mathrm{K} 7$ and $\mathrm{CHIII}(\mathrm{I}) \mathrm{Y} 6$ showed maximum ammonia production while other isolates showed moderate production of ammonia. Among the 10 isolates, three (CHIII(I)Y6, DDI(I) 1 and CHII(I)NA4) were recorded positive for $\mathrm{HCN}$ production, $\mathrm{CHIII}(\mathrm{I}) \mathrm{Y} 6$ and $\mathrm{DDI}(\mathrm{I}) 1$ isolates showing maximum $\mathrm{HCN}$ production by changing the color of filter paper orange to brown (Table 4).

Phosphate solubilization by selected isolates: All the selected isolates are phosphate solubilizing. Maximum zone was observed in isolate UHI(II)7 $(28 \mathrm{~mm})$. Significant zones were also seen in isolate CHII(II)K7 (26mm), DDV(I)3 (26mm), KUKI(II)6 (24mm) and DDI(I) $1(22 \mathrm{~mm}$ ) after 7 days of incubation (Figures 3 and 4; Table 5).

Antifungal activity: Several researchers have reported that increasing incidences of Fusarium wilt has causes major damage to production of basil [31-35]. More specifically, Fusarium oxysporum has been a major causal agent leading to disease throughout the world [31]. The symptoms include chlorosis, necrosis, wilt of stems and leaves, crown and root rot, formation of dark lesions and plant death. The antifungal activity of the isolates was tested against fungal pathogen i.e., Fusarium oxysporum in dual culture under in vitro conditions. Out of ten, only three isolates showed antagonistic potential (Figure 5; Table 5). The growth of the fungus was lesser as compared to the control plate. Isolate $\mathrm{CHII}(\mathrm{II}) \mathrm{K} 7$ exhibited greater inhibition followed by CHIII(I)Y6 and CHII(I)NA4 respectively.

Siderophore production and ACC-deaminase activity: Out of 10 selected isolates, isolate DDI(I) 1 was able to produce siderophore and it is confirmed by the development of orange halos surrounding

\begin{tabular}{|c|c|c|c|c|c|c|c|c|c|}
\hline Isolate(s) & Colour & Size & Shape & Elevation & Margin & Odor & Pigmentation & Surface & Opacity \\
\hline $\mathrm{CHII}(\mathrm{II}) \mathrm{K} 7$ & Yellowish green & Small & Round & Raised & Entire & None & Yellowish green & Smooth & Transparent \\
\hline CHIII(I)Y6 & Creamish & Medium & Irregular & Raised & Irregular & None & None & Shiny smooth & Opaque \\
\hline $\mathrm{DDI}(\mathrm{I}) 1$ & Yellowish green & Small & Round & Raised & Irregular & None & Yellowish green & Smooth & Transparent \\
\hline UHII(II)1 & White & Small & Round & Raised & Entire & None & None & Smooth & Opaque \\
\hline DDVII(II)1 & White & Small & Round & Raised & Entire & None & None & Smooth & Opaque \\
\hline KUKI(II)6 & Creamish & Small & Irregular & Raised & Irregular & None & None & Smooth & Opaque \\
\hline UHI(II)7 & White & Medium & Irregular & Raised & Irregular & None & None & Shiny smooth & Opaque \\
\hline DDII(II)1 & Creamish & Medium & Round & Raised & Irregular & None & None & Rough & Opaque \\
\hline CHII(I)NA4 & Yellowish & Small & Round & Raised & Entire & None & Yellowish & Rough & Opaque \\
\hline DDV(I)3 & Yellowish & Small & Round & Raised & Entire & None & Yellowish & Smooth & Opaque \\
\hline
\end{tabular}

Table 3: Morphological characteristics of selected PGPR isolates. 
Citation: Saharan BS, Verma S (2015) Evaluation of Rhizospheric Bacteria from Ocimum sp. as Potential Pgpr. J Microb Biochem Technol 7: 088095. doi:10.4172/1948-5948.1000187

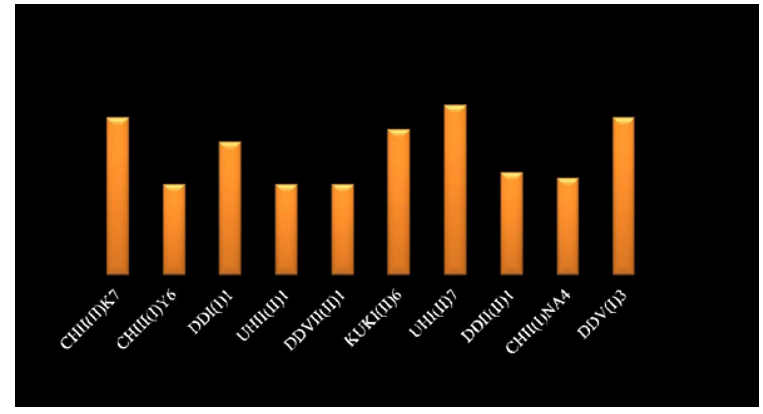

Figure 3: Phosphate Solubilization Index of Ocimumr hizosphere isolates.

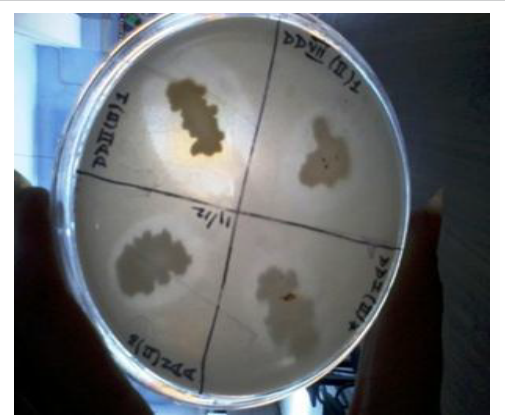

Figure 4: Isolates showing solubilization of phosphate.

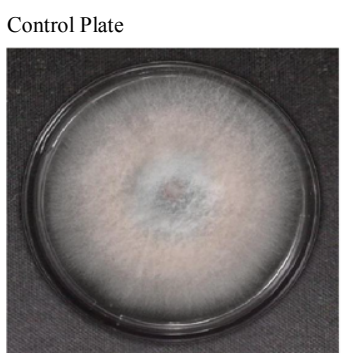

Test Isolate

Figure 5: Antifungal activity exhibited by isolate $\mathrm{CHII}(\mathrm{I}) \mathrm{NA} 4$ against Fusariumoxysporum. the colonies. ACC deaminase activity is helpful in maintaining plant growth and development, so its activity was measured. Isolate UHI(II)7 showed the highest ACC deaminase enzyme activity of $3.90 \mu \mathrm{mol}$ a-ketobutyrate/mg protein/h followed by isolate CHII(II)K7 which showed enzyme activity of $2.92 \mu \mathrm{mol} \alpha$-ketobutyrate $/ \mathrm{mg}$ protein $/ \mathrm{h}$.

Heavy metal tolerance by selected isolates: Selected isolates are found to be more tolerant at lower concentration of 25 and $100 \mu \mathrm{g} /$ $\mathrm{ml}$ and less tolerant at concentration of $400 \mu \mathrm{g} / \mathrm{ml}$. All selected isolates showed tolerance to $\mathrm{Ni}, \mathrm{Cu}$ and $\mathrm{Pb}$ at concentration $25 \mu \mathrm{g} / \mathrm{ml}$. But seven isolates were positive for $\mathrm{Zn}$ and $\mathrm{Co}$; six for $\mathrm{Cr}$; five for $\mathrm{Cd}$ and only four for $\mathrm{Hg}$ at concentration $25 \mu \mathrm{g} / \mathrm{ml}$. All selected isolates showed tolerance to nickel, copper and lead except $\mathrm{DDV}(\mathrm{I}) 3 \mathrm{for} \mathrm{Pb}$ at conc. $100 \mu \mathrm{g} / \mathrm{ml}$ (Figures 6 and 7; Table 6). 6(Zn, Co); 5(Cr); 4(Cd) and 3(Cr) no. of isolates were tolerant to $100 \mu \mathrm{g} / \mathrm{ml}$ concentration. For higher concentrations, like $400 \mu \mathrm{g} / \mathrm{ml}$; only CHII(II)K7 is tolerant to copper at concentration of $400 \mu \mathrm{g} / \mathrm{ml} .6(\mathrm{Zn}) ; 4(\mathrm{~Pb}) ; 3(\mathrm{Cd}, \mathrm{Cr})$ and $2(\mathrm{Co}, \mathrm{Hg})$ number of isolates were tolerant whereas all selected isolates were tolerant to nickel even at high concentration of $400 \mu \mathrm{g} / \mathrm{ml}$.

Effect of temperature on growth of isolates: It was observed that the growth of isolates on nutrient agar plates varied with temperature. The growth of all selected isolates was good in the temperature range of $20^{\circ} \mathrm{C}$ to $37^{\circ} \mathrm{C}$ except DDVII(II) 1 which was unable to grow at $20^{\circ} \mathrm{C}$. In addition, all selected isolates were found to grow at $45^{\circ} \mathrm{C}$ (Figures 8-10). On the contrary, isolates CHII(II)K7, UHI(II)7 and DDII(II)1 were found to grow at $10^{\circ} \mathrm{C}$ but the growth was less. Out of 10 selected isolates, five isolates have shown maximum PGP traits (CHII(II)K7, CHIII(I)Y6, DDI(I)1, UHI(II)7, CHII(I)NA4) i.e., IAA production, ammonia production, phosphate solubilization, HCN production, catalase production, heavy metal tolerance etc. The biochemical characteristics of these five isolates are given in Table 7. All the isolates were found to be positive for catalase test. On the basis of morphological and biochemical characterization, it was found that two isolates CHII(II)K7 and DDI(I)1 belongs to Pseudomonas sp., whereas CHIII(I)Y6, UHI(II)7 and CHII(I)NA4 belongs to Bacillus sp.

\section{Discussion}

Plant rhizosphere can be considered as an ecological niche for many various soil microorganisms because of the high amounts of nutrients available in the rhizosphere region. Growth enhancement maytake place due to plant hormone synthesis other PGP traits occurring in the rhizosphere [36-38]. PGPR with numerous PGP traits have been

\begin{tabular}{|c|c|c|c|c|c|c|c|c|c|}
\hline Isolate(s) & IAA & $\mathrm{HCN}$ & AMM & PSB & AFA & HMT & SID & CAT & ACC \\
\hline CHII(II)K7 & + & - & + & + & + & + & - & + & + \\
\hline CHIII(I)Y6 & + & + & + & + & + & + & - & + & - \\
\hline DDI(I)1 & + & + & + & + & - & + & + & + & - \\
\hline UHII(II)1 & - & - & + & + & - & + & - & + & - \\
\hline DDVII(II)1 & - & - & + & + & - & + & - & + & - \\
\hline KUKI(II)6 & - & - & + & + & - & + & - & + & - \\
\hline UHI(II)7 & + & - & + & + & - & + & - & + & + \\
\hline DDII(II)1 & + & - & + & + & - & + & - & + & - \\
\hline CHII(I)NA4 & + & + & + & + & + & + & - & + & - \\
\hline $\operatorname{DDV}(\mathrm{I}) 3$ & - & - & + & + & - & + & - & + & - \\
\hline
\end{tabular}

IAA: Indole Acetic Acid Production; HCN: Hydrogen Cyanide Production; AMM: Ammonia Production; PSB: Phosphate Solubilization; AFA: Antifungal Activity; HMT: Heavy Metal Tolerance; SID: Siderophore Production; CAT: Catalase Production; ACC: ACC Deaminase Activity; +: Positive Test; -: Negative Test.

Table 4: Characterization of selected bacterial strains for multiple plant growth promoting (PGP) traits. 
Citation: Saharan BS, Verma S (2015) Evaluation of Rhizospheric Bacteria from Ocimum sp. as Potential Pgpr. J Microb Biochem Technol 7: 088095. doi:10.4172/1948-5948.1000187

\begin{tabular}{|c|c|c|c|}
\hline \multirow[t]{2}{*}{ Isolate(s) } & \multicolumn{2}{|c|}{ Phosphate solubilization } & \multirow{2}{*}{$\begin{array}{c}\text { Antifungal activity against } \\
\text { Fusarium oxysporum } \\
\text { (\% inhibition) }\end{array}$} \\
\hline & Diameter of & Solubilization & \\
\hline & Zone in $\mathrm{mm}$ & index & \\
\hline CHIIIII)K7 & $26 \pm 0.00$ & 5.2 & $+++(61.10 \pm 1.34)$ \\
\hline CHIII(I)Y6 & $15 \pm 2.00$ & 3.0 & $++(58.88 \pm 1.07)$ \\
\hline $\mathrm{DDI}(\mathrm{l}) 1$ & $22 \pm 2.64$ & 4.4 & - \\
\hline UHII(II)1 & $15 \pm 0.00$ & 3.0 & - \\
\hline DDVII(II)1 & $15 \pm 2.00$ & 3.0 & - \\
\hline KUKI(II)6 & $24 \pm 2.64$ & 4.8 & - \\
\hline UHI(II)7 & $28 \pm 1.00$ & 5.6 & - \\
\hline DDII(II)1 & $17 \pm 2.64$ & 3.4 & - \\
\hline CHII(I)NA4 & $15 \pm 2.00$ & 3.2 & $++(42.21 \pm 0.00)$ \\
\hline $\operatorname{DDV}(\mathrm{I}) 3$ & $26 \pm 2.00$ & 5.2 & - \\
\hline
\end{tabular}

Table 5: Phosphate solubilization and antifungal activity by selected PGPR isolates.

\section{Zinc $(100 \mu \mathrm{g} / \mathrm{ml})$}

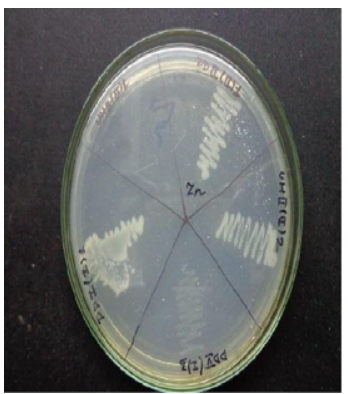

Figure 6: Isolates showing tolerance to zinc and nickel at $100 \mu \mathrm{g} / \mathrm{ml}$.

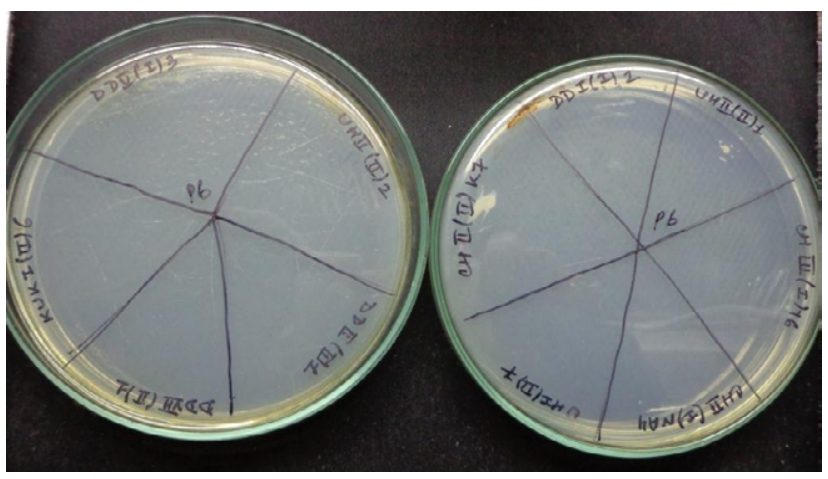

Figure 7: Isolates showing lead tolerance at $400 \mu \mathrm{g} / \mathrm{ml}$.

reported by researchers but there have been few findings on indigenous isolates of India [39]. Isolated bacteria were screened for different plant growth promotion activities and characterized by biochemical tests. IAA, a phytohormone, is well known as the most important native auxin. It may act as important signal molecule in the regulation of plant development. Of ten isolates, six isolates are positive for IAA production (Table 4). The potential for IAA synthesis varies with different species and strains as well as cultural condition, growth stage and availability of substrate [40]. The rhizospheric bacteria are more efficient auxin producers than those from the bulk soil [37]. About $80 \%$ of soil bacteria are evaluated to possess IAA producing potential.
IAA is reported to be involved in the epiphytic fitness of PGPR [41]. IAA produced by bacteria might modify the micro-habitates of epiphytic bacteria by enhancing the nutrient leakage of plant cells. Due to this availability of nutrients increases which may further help in the colonization of bacteria to the rhizosphere. In our study, the concentration of IAA produced ranges from 7.0 to $46.0 \mu \mathrm{g} / \mathrm{ml}$. Similar observations for IAA production have been reported by Malleswari and Bagyanarayan, 2013. Production of hydrogen cyanide has been found in P. fluoresens, P. aeruginosa and Chromobacterium uiolaceum [6]. Out of 10, three isolates viz., CHIII(I)Y6, DDI(I) 1 and CHII(I)NA4 showed HCN production [42] reported that IAA production is helpful in enhancement of plant growth and HCN production can be considered as defence regulator against phytopathogens. The most common way

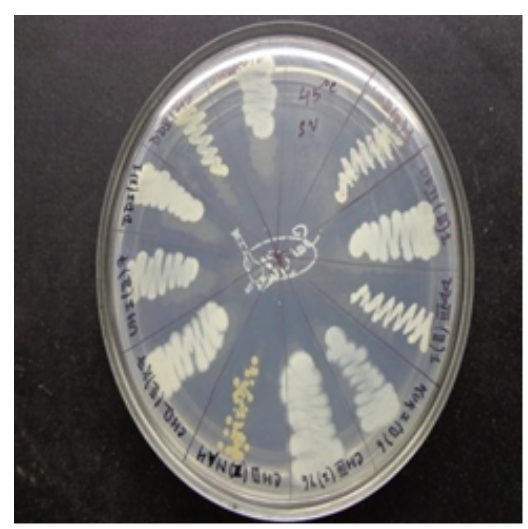

Figure 8: Growth of isolates at $45^{\circ} \mathrm{C}$.

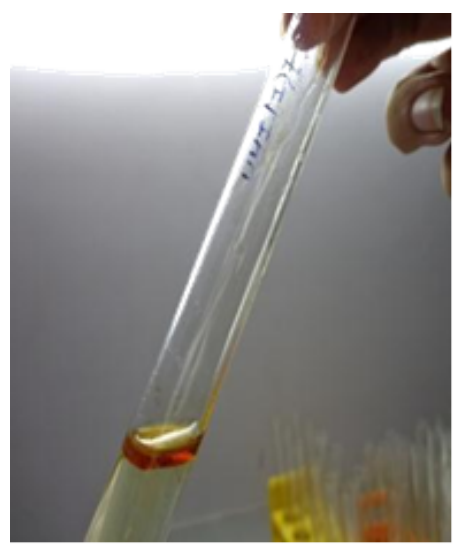

Figure 9: Isolates showing citrate utilization and indole production test.

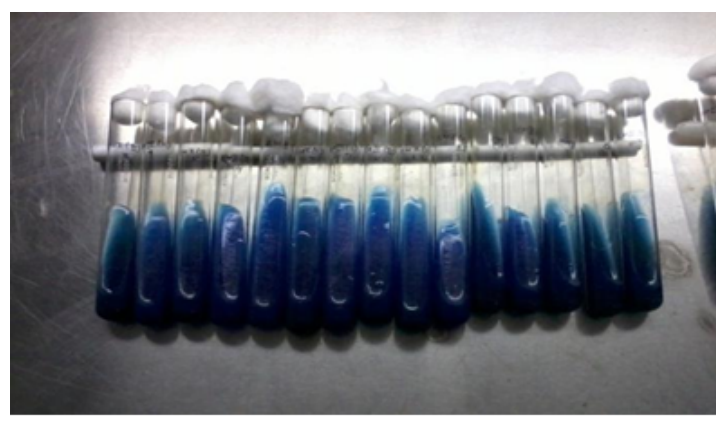

Figure 10: Citrate utilization test. 
Citation: Saharan BS, Verma S (2015) Evaluation of Rhizospheric Bacteria from Ocimum sp. as Potential Pgpr. J Microb Biochem Technol 7: 088095. doi:10.4172/1948-5948.1000187

\begin{tabular}{|l|c|c|c|c|c|c|c|c|c|c|}
\hline Heavy & CHII(I & CHIII(I)Y & DDI(I) & UHII(II)1 & DDVII(I & KUKI(II) & UHI(II) & DDII(II) & CHII(I)NA & DDV(I) \\
\hline metal $(\mu \mathrm{g} / \mathrm{ml})$ & I) K7 & $\mathbf{6}$ & $\mathbf{1}$ & & $\mathbf{I}) \mathbf{1}$ & $\mathbf{6}$ & $\mathbf{7}$ & $\mathbf{1}$ & $\mathbf{4}$ & $\mathbf{3}$ \\
\hline
\end{tabular}

Nickel (Ni)

\begin{tabular}{|l|l|l|l|l|l|l|l|l|l|l|}
\hline 25 & + & + & + & + & + & + & + & + & + & + \\
\hline 100 & + & + & + & + & + & + & + & + \\
\hline 400 & + & + & + & + & + & + & + \\
\hline
\end{tabular}

Zinc $(\mathrm{Zn})$

\begin{tabular}{|l|l|l|l|l|l|l|l|l|l|l|}
\hline 25 & + & + & + & - & + & + & + & + & + & + \\
\hline 100 & + & + & + & - & - & + & - & + \\
\hline 400 & + & + & + & - & - & + & - & + \\
\hline
\end{tabular}

Cobalt (Co)

\begin{tabular}{|l|l|l|l|l|l|l|l|l|l|}
\hline 25 & + & + & - & + & - & + & + & + & + \\
\hline 100 & + & + & - & - & - & + & + \\
\hline 400 & - & - & - & - & - & - & + \\
\hline
\end{tabular}

Cadmium (Cd)

\begin{tabular}{|l|l|l|l|l|l|l|l|l|l|}
\hline 25 & + & + & + & - & - & - & + & + & - \\
\hline 100 & - & + & + & - & - & - & + \\
\hline 400 & - & - & + & - & - & - & + \\
\hline
\end{tabular}

Lead $(\mathrm{Pb})$

\begin{tabular}{|c|c|c|c|c|c|c|c|c|c|c|}
\hline 25 & + & + & + & + & + & + & + & + & + & + \\
\hline 100 & + & + & + & + & + & + & + & + & + & - \\
\hline 400 & & + & + & + & - & - & - & - & - & - \\
\hline \multicolumn{11}{|c|}{ Copper (Cu) } \\
\hline 25 & & + & + & + & + & + & + & + & + & + \\
\hline 100 & & + & + & + & + & + & + & + & + & + \\
\hline 400 & & - & - & - & - & - & - & - & - & - \\
\hline
\end{tabular}

Chromium $(\mathrm{Cr})$

\begin{tabular}{|c|c|c|c|c|c|c|c|c|c|}
\hline 25 & + & - & + & + & - & + & + & - & + \\
\hline 100 & + & - & + & + & - & + & - & - & + \\
\hline 400 & - & - & + & + & - & + & - & - & - \\
\hline \multicolumn{10}{|c|}{ Mercury $(\mathrm{Hg})$} \\
\hline 25 & - & - & + & - & + & - & + & + & - \\
\hline 100 & - & - & - & - & + & - & - & - & - \\
\hline 400 & - & - & - & - & + & - & - & - & - \\
\hline
\end{tabular}

Table 6: Heavy metal tolerance of selected PGPR isolates.

\begin{tabular}{|l|c|c|c|c|c|}
\hline Test(s) & CHII(II)K7 & CHIII(I)Y6 & DDI(I)1 & UHI(II)7 & CHII(I)NA4 \\
\hline Gram & -ve & $+v e$ & $-v e$ & $+v e$ & $+v e$ \\
\hline Reaction & & & & & \\
\hline Shape & Rods & rods & rods & rods & rods \\
\hline Indole & - & - & - & - & - \\
\hline Methyl-red & - & - & - & + & - \\
\hline VP & - & + & - & + & + \\
\hline Citrate & + & + & + & - & + \\
\hline Catalase & + & + & + & + & + \\
\hline Oxidase & - & - & + & + & - \\
\hline H2S & - & - & - & - & - \\
\hline Nitrate & + & + & + & + & + \\
\hline reduction & & & & & \\
\hline
\end{tabular}

Table 7: Biochemical identification of selected PGPR isolates.

for increasing the availability of nutrients to the plants is solubilization of phosphorus in the rhizosphere by PGPR. The phosphate-solubilising Pseudomonas spp. increased growth as well as phosphorus content of maize. In our study, maximum zone of solubilization $(28 \mathrm{~mm})$ was observed for isolate UHI(II)7. O'Sullivan DJ et al. [43] reported Bacillus sp., Providencia sp., Brevundimonas and Alcaligenes as phosphate solubilizers. Solubilization of phosphorus have been well documented in Alcaligenes, Bacillus sp. [44]. Siderophore production is another important trait of PGPR $[45,46]$ and observed the siderophore production in Pseudomonas that exhibited antagonism to plant pathogens such as Fusarium oxysporum and Rhizoctonia solani. In the present study, only isolate DDI(I)1 was able to produce siderophore. Among the isolates screened for ACC deaminase activity, only two isolates exhibited this trait viz., CHII(II)K7 and UHI(II)7. Providencia sp. (AW5) and Alcaligenes sp. (AW10) possess ACC deaminase activity (3.13 and $9.5 \mu \mathrm{m} \alpha$-ketobutyrate $/ \mathrm{mg} / \mathrm{h}$, respectively) [2]. In our study, the two isolates showed activity of $3.90 \times 10^{-6} \mu \mathrm{mol} \alpha$-keto butyrate/ $\mathrm{mg}$ protein/ $\mathrm{h}$ and $2.92 \times 10^{-6} \mu \mathrm{mol} \alpha$-keto butyrate/mg protein/h by isolate $\mathrm{UHI}(\mathrm{II}) 7$ and $\mathrm{CHII}(\mathrm{II}) \mathrm{K} 7$. Similar findings have been reported by other workers $[47,48]$. Plant growth by ACC deaminase producing Micrococcus sp. NII-0909 was reported [49]. Three bacterial isolates showed positive test for growth inhibition of fungus Fusarium oxysporum. Production of lytic enzymes by Pseudomonas have been reported in several studies for control of plant pathogenic fungi $[42,38]$. All the test bacterial isolates in the present study showed positive test for catalase and ammonia production. It has been found that plant growth can be enhanced by decreasing the levels of toxic heavy metals and that the microorganisms have developed these mechanisms for increasing 
Citation: Saharan BS, Verma S (2015) Evaluation of Rhizospheric Bacteria from Ocimum sp. as Potential Pgpr. J Microb Biochem Technol 7: 088095. doi:10.4172/1948-5948.1000187

their chances of survival in the heavy metal containing environment [50]. Microorganisms that possess plant growth promoting traits and are metal tolerant may be helpful in the recolonization of the plant rhizosphere in polluted soils.

\section{Summary and Conclusion}

These studies concluded that the five chosen isolates viz., $\mathrm{CHII}(\mathrm{II})$ K7, DDI(I)1, CHIII(I)Y6, UHI(II)7 and CHII(I)NA4 which were positive for maximum PGP traits have proven to be most promising and can be selected as effective PGPR strains. The isolates namely $\mathrm{CHII}(\mathrm{II}) \mathrm{K} 7$ and $\mathrm{UHI}(\mathrm{II}) 7$ have been reported as potential PGPR with best activities and they were further characterized by $16 \mathrm{~S}$ rDNA sequencing as Pseudomonas sp. CHII(II)K7 and Bacillus licheniformis UHI(II)7, respectively.

With the success story of this primary screening protocol, we can further move on to their assessment under field conditions which might be useful for the development of potential inoculants/biofertilizer for increasing the growth and productivity of medicinal plants.

\section{References}

1. Narula N, Saharan B S, Kumar V, Bhatia R, Bishnoi L K, et al. (2005) Impact of the use of biofertilizers on cotton (Gossypium hirsutum) crop under irrigated agro-ecosystem. Archives Agro. Soil Sci 51: 69-77.

2. Rana A, Saharan B, Joshi M, Prasanna R, Kumar K, et al. (2011) Identification of multi-trait PGPR isolates and evaluating their potential as inoculants for wheat. Ann Microbiol 61:893-900.

3. Saharan BS, Nehra V (2011) Assessment of Plant growth promoting attributes of cotton (Gossypium hirsutum) rhizosphere isolates and their potential as bioinoculants. J Environ Res Dev 5: 575-583.

4. Jamil A, Shahid M, Khan MM, Ashraf M (2007) Screening of some medicinal plants for isolation of antifungal proteins and peptides. J Bot 39: 211-221.

5. Prasad SK, Sharma S, Singh V (2013) Harnessing PGPR from rhizosphere of prevalent medicinal plants in tribal areas of Central India. Res J Biotech 8 . 76-85.

6. Singh V, Sharma S, Shukla KP (2013) Harnessing PGPR from rhizosphere of prevalent medicinal plants in tribal areas of Central India. Res J Biotech 8 (5): 76-85

7. Glick BR (1995) The enhancement of plant growth by free-living bacteria. Can $J$ Microbiol 41:109-117.

8. Kloepper JW (1993) Plant growth-promoting rhizobacteria as biologica control agents. In: Soil Microbial Ecology: Applications in Agricultural and Environmental Management, Marcel Dekker, New York, pp. 255-274.

9. Bloemberg GV, Lugtenberg BJ (2001) Molecular basis of plant growth promotion and biocontrol by rhizobacteria. Curr Opin Plant Biol 4: 343-350.

10. Persello-Cartieaux F, Nussaume L, Robaglia C (2003) Tales from the underground: Molecular plant-rhizobacteria interactions. Plant Cell Environ 26 189-199.

11. Nelson LM (2004) Plant growth promoting rhizobacteria (PGPR): Prospects for new inoculants. Online. Crop Management. doi:10.1094/CM-2004-0301-05-RV.

12. Rodríguez H, Fraga $\mathrm{R}$ (1999) Phosphate solubilizing bacteria and their role in plant growth promotion. Biotechnol Adv 17: 319-339.

13. Sturz AV, Nowak J (2000) Endophytic communities of rhizobacteria and the strategies required to create yield enhancing associations with crops. Appl Soil Ecol 15: 183-190.

14. Sudhakar P, Chattopadhyay GN, Gangwar SK, Ghosh JK (2000) Effect of foliar application of Azotobacter, Azospirillum and Beijerinckia on leaf yield and quality of mulberry (Morus alba). J Agric Sci 134: 227-234.

15. Karlidag H, Esitken A, Turan M, Sahin F (2007) Effects of root inoculation of plant growth promoting rhizobacteria (PGPR) on yield, growth and nutrient element contents of apple. Sci Hortic 114: 16-20.

16. Pattanayak P, Behera P, Das D, Panda SK (2010) Ocimum sanctum Linn. A reservoir plant for therapeutic applications: An overview. Pharmacogn Rev 4 95-105.

17. Singh V, Amdekar S, Verma O (2010) Ocimum Sanctum (tulsi): Biopharmacological Activities. Webmed Central Pharmacol 1: WMC001046.

18. Singh S, Agrawal SS (1991) Anti-asthematic and anti-inflammatory activity of Ocimum sanctum Lin. International Journal of Pharmacognosy 29(4): 306-310.

19. Ashrafuzzaman M, Hossen $F A$, Ismail M R, Hoque Md A, Islam M Z, et al. (2009) Efficiency of plant growth-promoting rhizobacteria (PGPR) for the enhancement of rice growth. African J Biotechnol 8: 1247-1252.

20. Okon Y, Albrecht SL, Burris RH (1977) Methods for Growing Spirillum lipoferum and for Counting It in Pure Culture and in Association with Plants. Appl Environ Microbiol 33: 85-88.

21. Gordon SA, Weber RP (1951) Colorimetric Estimation of Indoleacetic Acid Plant Physiol 26: 192-195.

22. Cappuccino JC, Sherman N (1992) Microbiology: A Laboratory Manual, New York, pp. 125-179.

23. Lorck H (1948) Production of hydrocyanic acid by bacteria. Plant Physiol 1 142-146.

24. Pikovaskaya RI (1948) Mobilization of phosphorus in soil in connection with vital activity of some microbial species. Microbiol 17: 362-370.

25. Tiwari R, Kalra A, Darokar MP, Chandra M, Aggarwal N, et al. (2010) Endophytic bacteria from Ocimum sanctum and their yield enhancing capabilities. Curr Microbiol 60: 167-171.

26. Schwyn B, Neilands JB (1987) Universal chemical assay for the detection and determination of siderophores. Anal Biochem 160: 47-56.

27. Dworkin M, Foster JW (1958) Experiments with some microorganisms which utilize ethane and hydrogen. J Bacteriol 75: 592-603.

28. Penrose DM, Glick BR (2003) Methods for isolating and characterizing ACC deaminase-containing plant growth-promoting rhizobacteria. Physiol Plant 118 10-15.

29. Cervantes-Vega C, Chávez J, Córdova NA, de la Mora P, Amador Velasco $J$ (1986) Resistance to metals by Pseudomonas aeruginosa clinical isolates. Microbios 48: 159-163.

30. Cappuccino J, Sherman N (2010) Microbiology: A Laboratory Manual (9thedn.) Benjamin Cummings Publishing Company, USA, pp. 560.

31. Gamliel A, Katan T, Yunis H Katan J (1996) Fusarium wilt and crown rot of sweet basil: involvement of soilborne and airborne inoculum. Phytopathol 86 56-62.

32. Fravel DR, Larkin RP (2002) Reduction of fusarium wilt of hydroponically grown basil by Fusarium oxysporum strain CS-20. Crop Prot 21: 539-43.

33. Swart L, Van Niekerk JM (2003) First record of Fusarium oxysporum f.sp basilici occurring on sweet basil in South Africa. Australasian Plant Pathol 32 125-6.

34. Biris D, Vakalounakis DJ, Klironomou E (2004) Fusarium wilt of basil in Greece: foliar infection and cultivar evaluation for resistance. Phytoparasitica 32: 160166.

35. Moya MLG, Aguilar ML, Blanco R, Kenig A, Gomez, et al. (2004) Fusarium wilt on sweet basil: cause and sources in southeastern Spain. Phytoparasitica 32: 395-401.

36. Arshad M, Frankenberger WT (1993) Microbial production of plant growth regulators. In: Soil Microbial Ecology: Applications in Agricultural and Environmental Management.

37. Glick BR, Bashan Y (1997) Genetic manipulation of plant growth-promoting bacteria to enhance biocontrol of phytopathogens. Biotechnol Adv 15: 353-378.

38. Ahmad F, Ahmad I, Khan MS (2008) Screening of free-living rhizospheric bacteria for their multiple plant growth promoting activities. Microbiol Res 163: 173-181.

39. Abbas Z, Okon Y (1993) Plant growth promotion by Azotobacter paspali in the rhizosphere. Soil Biol. Biochem. 25:1075-1083.

40. Mirza MS, Ahmad W, Latif F, Haurat J, Bally R, et al. (2001) Isolation, partial characterization, and the effect of plant growth-promoting bacteria (PGPB) on micro-propagated sugarcane in vitro. Plant Soil. 237:47-54. 
Citation: Saharan BS, Verma S (2015) Evaluation of Rhizospheric Bacteria from Ocimum sp. as Potential Pgpr. J Microb Biochem Technol 7: 088095. doi:10.4172/1948-5948.1000187

41. Holguin G, Glick BR (2003) Transformation of Azospirillum brasilense Cd with an ACC deaminase gene from enterobacter cloacae UW4 fused to the Tet gene promoter improves its fitness and plant growth promoting ability. Microb Ecol 46: 122-133.

42. Blumer C, Haas D (2000) Mechanism, regulation, and ecological role of bacterial cyanide biosynthesis. Arch Microbiol 173: 170-177.

43. Rana A, Saharan B, Kabi SR, Prasanna R, Shivay YS, et al. (2011) Providencia a PGPR with biocontrol potential elicits defense enzymes in wheat. Ann PI Protec Sci 19: 138-141.

44. Forchetti G, Masciarelli O, Alemano S, Alvarez D, Abdala G (2007) Endophytic bacteria in sunflower (Helianthus annuus L.): isolation, characterization, production of jasmonates and abscisic acid in culture medium. Appl Microbiol Biotechnol 76: 1145-1152.

45. O'Sullivan DJ, O'Gara F (1992) Traits of fluorescent Pseudomonas spp. involved in suppression of plant root pathogens. Microbiol Rev 56: 662-676.
46. Nagrajkumar M, Bhaaskaran R, Velazhahan R (2004) Involvement of secondary metabolites and extracellular lytic enzymes produced by Pseudomonas fluorescens in inhibition of Rhizoctonia solani, the rice sheath of blight pathogen. Microbiol Res 159: 73-81.

47. Javier DC, Milagros LB, Ricardo PG (2004) Screening for plant growthpromoting rhizobacteria in Chamaecytisus proliferus (tagasaste), a forage treeshrub legume endemic to the Canary Islands. Plant Soil 266: 261-272.

48. Fischer SE, Fischer SI, Magris S, Mori GB (2007) Isolation and characterization of bacteria from the rhizosphere of wheat. World J Microbiol Biotechnol 23 895-90.

49. Dastager SG, Deepa CK, Pandey A (2010) Isolation and characterization of novel plant growth promoting Micrococcus sp NII-0909 and its interaction with cowpea. Plant Physiol Biochem 48: 987-992.

50. Burd GI, Dixon DG, Glick BR (1998) A plant growth-promoting bacterium that decreases nickel toxicity in seedlings Appl Environ Microbiol 64: 3663-3668. 